\title{
Toward in vitro fertilization in Brachiaria spp.
}

\author{
Diva M. A. Dusi • Elizangela R. Alves • \\ Michiel T. M. Willemse • Rosana Falcão • \\ Cacilda B. do Valle $\cdot$ Vera T. C. Carneiro
}

Received: 19 June 2009/ Accepted: 20 January 2010/Published online: 5 February 2010

(C) Springer-Verlag 2010

\begin{abstract}
Brachiaria are forage grasses widely cultivated in tropical areas. In vitro pollination was applied to accessions of Brachiaria spp. by placing pollen of nondehiscent anthers on a solid medium near isolated ovaries. Viability and in vitro germination were tested in order to establish good conditions for pollen development. Comparing sexual to apomictic plants, apomictic pollen has more abortion after meiosis during the microspore stage and a lower viability and, of both types, only some plants have sufficient germination in a high sugar concentration. Using in vitro pollination with the sexual plant, the pollen tube penetrates into the nucellus and micropyle, but the embryo sac degenerates and collapses. In the apomictic $B$. decumbens, in vitro pollination leads to the transfer of the sperm nuclei into the egg cell and the central cell. The results are discussed according to normal fertilization and barriers in sexual and apomictic plants.
\end{abstract}

Communicated by Scott Russell.

D. M. A. Dusi $(\bowtie)$ · E. R. Alves · R. Falcão · V. T. C. Carneiro Embrapa Genetic Resources and Biotechnology, Parque Estação Biológica, Av. W 5 Norte Final, CP 02372, Brasília, DF 70770-917, Brazil

e-mail: diva@cenargen.embrapa.br

E. R. Alves - V. T. C. Carneiro

Cell Biology Department,

University of Brasilia (UnB), Brasília, DF, Brazil

M. T. M. Willemse

Wageningen University and Research Centre,

Wageningen, The Netherlands

C. B. do Valle

Embrapa Beef Cattle, Campo Grande, MS, Brazil
Keywords Brachiaria sp. · In vitro pollination . Incompatibility · Pollen germination · Pollen viability

\section{Introduction}

Brachiaria is a genus of forage grasses widely cultivated in tropical areas. In Brazil, an estimated area of 175 million hectares of pasture land is used to sustain a cattle population of about 170 million head (IBGE 2006). In the Cerrado region, in which about $35 \%$ of the Brazilian cattle are grown, Brachiaria covers an estimated area of about 43 million hectares (Karia et al. 2006). Two apomictic adapted varieties, Brachiaria brizantha cv. Marandu and $B$. decumbens cv. Basilisk account for almost $80 \%$ of the commercial seeds of tropical forages in Brazil (de Andrade 2001). Due to the asexual mode of reproduction by apomixis, these plants are clones characterized by wide monocultures, which potentially represent a significant economical and environmental risk. For these reasons, improved cultivars of Brachiaria with enhanced forage quality and greater resistance to pests and diseases are strongly needed (Lapointe and Miles 1992; Valério et al. 1996; do Valle and Savidan 1996; Miles et al. 1996; Karia et al. 2006).

The basic number of chromosomes for the majority of species in the genus Brachiaria is nine (Risso-Pascotto et al. 2006). In this genus, irregular meiosis and polyploidy are often associated with apomixis, whereas regular chromosome pairing, as usually happens during premeiosis in diploids, is related with sexuality (do Valle 1986). Facultative apomixis, as represented by the percentage of sexuality expressed at the embryological level, is not necessarily equivalent to the presence of off-types observed in the field (Miles and do Valle 1991). Apomictic 
reproduction predominates, however, and most apomictic plants of Brachiaria species are tetraploid, $(2 n=4 x=36)$ whereas sexual plants are diploid $(2 n=2 x=18$ ) (do Valle 1991). Due to their difference in ploidy level, hybrids from crosses between sexual and apomictic plants are difficult to obtain (do Valle 1990). To avoid this problem, breeders typically use an artificially induced sexual tetraploid of B. ruziziensis (Gobbe et al. 1981; Swenne et al. 1981) as an intermediate cross-parent to enhance variability in apomictic tetraploid $B$. decumbens and $B$. brizantha (do Valle 1990; Miles et al. 1996). More recently, artificially induced sexual tetraploids of $B$. brizantha (Pinheiro et al. 2000; Araujo et al. 2005) were obtained in order to allow greater diversity in intra-specific crosses. This approach permits introduction of some degree of variability into commercial cultivars of Brachiaria. One sexual accession of B. humidicola with 36 chromosomes was used to obtain an intraspecific hybrid population (do Valle et al. 2008a, b). For now, most of the Brachiaria improvement consists in the selection of superior genotypes among the naturally existing ones.

Self-incompatibility is reported to occur in sexual plants for the genus Brachiaria. Ngendahayo (1988) noted that using a high number of pollen grains resulted in only a low percentage of pollen tubes reach the ovary. In the sexual B. brizantha, one pollen tube and rarely two were found at the micropyle of the ovary (Araujo et al. 2007). In the sexual $B$. decumbens, only one in five pistils had a pollen tube inside the ovule $24 \mathrm{~h}$ after pollination. In the hairy region of the stigma of Pennisetum, fewer pollen tubes than in the stigmatic hairs were observed, as a consequence of the high density of pollen tubes reducing the tube growth (Kaushal and Sidhu 2000). In contrast to Brachiaria, Pennisetum had many pollen tubes reach the ovary, and this number increased with time after pollination. In rice, most of the pollen tubes growing into the style entered the ovary and many pollen tubes were viewed at the bottom of the ovary, but only one entered the micropyle (Chen et al. 2008).

Brachiaria is a pseudogamic apomict; thus, pollination and the fertilization of the polar nucleus are still required to form the endosperm and to develop seeds, although embryo development is independent of fertilization (Ngendahayo 1988; Alves et al. 2001). In the apomictic Brachiaria, several apospores develop into embryo sacs of the Panicum type (Ngendahayo 1988; do Valle 1990; Dusi and Willemse 1999b; Araujo et al. 2000). In sexual plants, the fusion of the sperm nucleus with the egg cell nucleus initiates the zygote, while the other sperm cell nucleus fuses with the diploid central cell nucleus and leads to the development of the endosperm (Alves et al. 2001; Araujo et al. 2007).

The establishment of in vitro fertilization in general and specifically in Brachiaria can be useful as a tool for plant breeding (Willemse et al. 1995; Higashiyama et al. 1998). Culture media are used to germinate pollen and to maintain the viability of the buds, or organs. This method permits reproduction to overcome incompatibility barriers and expands the possibilities of intra-specific, inter-specific and inter-generic crossings (Willemse 1999). It can also allow the fertilization process to be studied in detail, which may be of significant interest for the analysis of gene expression in particular wild apomictic plants. The effects of pollen tube attraction, pollen tube penetration and fertilization can be timed, and the regulatory steps concerning the ovule activation and the different steps of the reproduction processes traced.

In nature, seed set and offspring production from sexual accessions of Brachiaria is very low and therefore sexual processes are difficult to use for breeding. Nevertheless, crossings using sexual plants may lead to a better crop for cattle feeding. The introduction of in vitro pollination may help to overcome some barriers to recombination. In vitro pollination has been applied to few grasses including Zea mays (Sladký and Havel 1976).

In this paper, major factors necessary for establishing a method of in vitro pollination and fertilization of Brachiaria such as choice of genotype, pollen viability, anther and ovary condition and culture media were analyzed, as well as the progamic phase during in vitro fertilization.

\section{Materials and methods}

\section{Plant material}

Brachiaria genotypes used were germplasm accessions of Embrapa. Brachiaria decumbens accessions BRA 00430 (DS1 sexual), BRA 000191 (DA1 apomictic) and B. humidicola BRA005118 (HA1 apomictic); were cultured in field sites of Embrapa Genetic Resources and Biotechnology, Brasilia-DF, Brazil. B. ruziziensis sexual (RS1and RS3); B. decumbens sexual BRA 00430 (DS1), apomictic BRA 000191 (DA1) and BRA 001058 (DA2); and $B$. humidicola BRA 005118 (HA1) were maintained in field sites of Embrapa Beef Cattle, Campo Grande, MS, Brazil. All sexual genotypes are $2 n=2 x=18$ and the apomicts are $2 n=4 x=36$, with the exception of B. ruziziensis RS3, which is a tetraploid sexual, and the apomictic B.humidicola HA1, which is $2 n=6 x=54$ (Boldrini et al. personal communication).

Pollen viability and tube growth

Microspore and pollen developmental stages were estimated from mature anthers by staining of nuclei with $0.001 \mathrm{~g} / \mathrm{l}$ DAPI (4'-6'-diamidino-2-phenylindole) in water 
at $\mathrm{pH}$ 4.0. The stained pollen grains were observed using a UV fluorescence microscope (Axiophot, Zeiss) with excitation filter $365 \mathrm{~nm}$ (BP 365/12) and $397 \mathrm{~nm}$ emission wavelength (dichroic beam splitter FT 395). When staining with $1 \%$ lissamine green in isotonic solution, microspore and pollen viability was determined using light microscopy. Pollen grains displaying a blue/green content were considered as dead (Holmberg 1961). To establish pollen development stages, changes in volume of grain and vacuole of pollen were noted.

For pollen tube growth in vitro, pollen from accessions RS1, RS3, HA1, DS1, DA2, DA1, were collected from anthers of plants in the field of Embrapa Beef Cattle, at the very beginning of anther dehiscence. Pollen grains were inoculated in a basic medium with $0.03 \mathrm{~g} / \mathrm{l}$ boric acid and $0.03 \mathrm{~g} / \mathrm{l}$ calcium nitrate or calcium chloride. Sucrose was used as the carbohydrate source in different concentrations from 10 to $40 \%$. The media were solidified with $0.19 \%$ agar or $0.15 \%$ Phytagel. Pollen germination was observed with a Zeiss Stemi SV11 stereomicroscope. After $2 \mathrm{~h}$ or $4 \mathrm{~h}$ post-pollination, the percentage of pollen germination was determined for the different accessions of Brachiaria.

Pollen tube growth on stigma and style was detected after 4, 24 and $48 \mathrm{~h}$ after pollination (HAP). Pollinated pistils were collected and placed in Carnoy's fixativeethanol:acetic acid 3:1(v:v)-for $30 \mathrm{~min}$. After transferring to $70 \%$ ethanol for $1 \mathrm{~h}$, pistils were washed three times in water and kept in $8 \mathrm{~N} \mathrm{NaOH}$ for at least $3 \mathrm{~h}$. Thereafter, specimens were placed in $1 \%$ aniline blue in $0.15 \mathrm{M}$ $\mathrm{K}_{2} \mathrm{HPO}_{4}$, deposited on a glass slide in a drop of glycerin and examined using a fluorescence UV-microscope (Axiophot, Zeiss) with excitation filter $365 \mathrm{~nm}$ (BP 365/12) and $397 \mathrm{~nm}$ emission wavelength (dichroic beam splitter FT 395). Depending on the $\mathrm{pH}$, the pollen tubes fluoresced blue or yellow.

\section{Anther and ovary condition}

To select the best condition for pollen tube growth, already dehiscent anthers, newly dehiscent anthers and non-dehiscent anthers from sexual DS1 were collected from flowers just before floral anthesis. The closed anthers were deposited in Petri dishes under incandescent light for opening. Pollen were collected and transferred to Petri dishes containing pollen germination medium (33\% sucrose, $0.03 \mathrm{~g} / \mathrm{l}$ boric acid and $0.03 \mathrm{~g} / \mathrm{l}$ calcium chloride in water, $0.19 \%$ agar). Pollen tube germination was observed using a stereomicroscope (Zeiss-SV11). Each treatment consisted of four repetitions of approximately 500 pollen grains.

Racemes with open flowers were used for collection of ovaries. Racemes of different accessions, DS1, DA1 and HA1, with only one or two open flowers were collected on the day before pollination, placed in water in a jar to avoid dehydration and left overnight in the dark at room temperature (RT). The anatropous ovules were dissected at their base by cutting the funicle.

In vitro pollination

To conduct in vitro pollination experiments, pollen and dissected ovaries were placed on a pollen germination medium as described by Willemse et al. (1995). These incubations lead to pollen tube penetration of the micropyle, entrance of the synergid and release and nuclear transfer into the egg cell and central cell respectively. Each one of the pollination experiments was done within one plant, and only self-pollinations were used. The best way to perform in vitro pollination is to use basally sectioned pistils and placing pollen near their base. Pistils from recently open flowers were collected using an incision at the basal part, and placed in the pollen germination medium, 10 pistils per Petri dish. The anthers were collected and placed in a sterile Petri dish under incandescent light to open. Anthers with a small opening area were forced to release pollen with tweezers, and pollen was spread directly from the anther near the basal side of the pistil. Petri dishes were kept in the dark at RT during the experiments. Pollen tube growth was observed after 2 and $4 \mathrm{~h}$. To verify if the pollen tubes were adhered to the ovary, after $24 \mathrm{~h}$ or $48 \mathrm{~h}, 121$ ovaries of DS1, 10 ovaries of DA1 and 15 ovaries of HA1 were collected from the Petri dishes with tweezers and those with attached pollen tubes were counted. To confirm whether pollination was successful, 41 ovaries of DS1 with attached pollen tubes were placed in Carnoy's fixative (ethanol:acetic acid, 3:1 v/v) for a minimum of $30 \mathrm{~min}$. These ovaries were then transferred to $70 \%$ ethanol for $1 \mathrm{~h}$, washed three times in water and kept in $8 \mathrm{~N} \mathrm{NaOH}$ for at least $3 \mathrm{~h}$. Thereafter, specimens were placed in $1 \%$ aniline blue in $0.15 \mathrm{M} \mathrm{K}_{2} \mathrm{HPO}_{4}(\mathrm{pH} 8.2)$ deposited on a glass in a drop of glycerin and examined using a fluorescence microscope at a wavelength of $360 \mathrm{~nm}$. To observe the discharge of sperm cells inside the embryo sac at 48 HAP, 5 ovaries of DS1, 5 ovaries of HA1 and 4 ovaries of DA1 were fixed in FAA (37\% formalin, acetic acid, 96\% ethanol and water at the ratio 3:3:40:14) for $24 \mathrm{~h}$. These were then dehydrated through an ethanol series $(70,80$ and $95 \%)$ for $1 \mathrm{~h}$ at $\mathrm{RT}$, transferred to $95 \%$ ethanol plus embedding solution (JB-4 Embedding Kit, PolyScience) 1:1 (v:v) at RT. Subsequently, the samples were kept overnight in the pure embedding solution at $4{ }^{\circ} \mathrm{C}$. The embedding solution was refreshed and samples were kept for 2 more hours under vacuum at RT. The samples were then positioned in plastic capsules at $4{ }^{\circ} \mathrm{C}$ and transferred to $60^{\circ} \mathrm{C}$ for polymerization. Semi-thin sections $(5 \mu \mathrm{m})$ were obtained, deposited in glass slides and stained 
in a water solution containing $0.9 \%$ Astra blue and $0.1 \%$ Safranin. Excess staining was removed with $70 \%$ ethanol. Specimens were mounted on slides and analyzed with a Zeiss-Axiophot light microscope.

The viability of the ovaries can be extended to 48 HAP by changing the sugar concentration of the medium to $6 \%$.

\section{Results}

Pollen viability and tube growth

Pollen viability in an anther is critical to in vitro pollination experiments. Therefore, the determination of the pollen viability was done on all different plants of Brachiaria spp. The vital stain lissamine green discriminates well between dead and living pollen. To get an indication of the viability during pollen development, three phases were distinguished using DAPI staining and morphological characteristics. Mature pollen is large and contains three nuclei: one of the vegetative cell and two of each sperm cell. Vacuolated pollen is smaller and shows the nucleus of the vegetative and generative cell. The microspore stage has one nucleus. A mature anther can have all three phases and the percentage of each phase was noted.

The viability and characteristics of pollen development for each accession studied are shown in Table 1. All pollen that was alive and had three nuclei was considered viable. In our experimental conditions, two of the sexual diploids $(2 n=2 x)$, RS1 and DS1, had around $80 \%$ of viable mature pollen, but two of the polyploid apomicts $(2 n=4 x$ or $2 n=6 x$ ) had viability around $40 \%$. While the diploid sexual plants had a normal development pathway, the polyploid plants showed delayed development and premature microspore abortion. The presence of degenerated cytoplasm and remnants of only thin pollen walls point to lethality from the beginning of the microspore stage.

Germination medium on culture plates was optimized to achieve in vitro fertilization with a high percentage of growing pollen tubes. Several sucrose concentrations were tested for germination of mature pollen collected from anthers. A gradient from 10 to $40 \%$ sucrose was made and the highest germination percentage noted. As shown in Table 1, in vitro pollen germination is highly dependent on the species as well as on sucrose concentration. Within the tested conditions, B. decumbens sexual diploid (DS1) and tetraploid apomictic (DA2) showed the best in vitro pollen tube growth in $30-33 \%$ sucrose. B. decumbens tetraploid apomictic (DA1), and diploid and tetraploid sexual B. ruziziensis (RS1, RS3) had very low germination. $B$ humidicola HA1 presented an intermediate germination capacity and pollen tube growth.

After in vivo pollination, pollen tubes were soon observed entering the stigma (Fig. 1a). Aniline blue dye was used to show the callose present in the pollen tube wall. The number of pollen tubes was strongly reduced entering the style and only one reached the micropyle (Fig. 1b). In the sexual B. decumbens, DS1, only one of 5 pistils had a pollen tube penetrating the ovule after $24 \mathrm{~h}$. DAPI labeling revealed that the sperm nuclei are present in pollen tubes of medium length, i.e. a pollen tube length of more than 10 times the pollen diameter.

\section{Anther maturity and ovary condition}

Pollen collected from dehiscent anthers had a $10 \%$ rate of in vitro germination (Fig. 1c). However, the best percentage of in vitro germination, about $90 \%$, was obtained from mature anthers. Such anthers were collected immediately before anthesis or at anthesis and opened under

Table 1 Percentage of live and dead pollen during three phases of development in a mature anther produced by Brachiaria species of different ploidy levels and range of sucrose percentages resulting in the highest average of pollen germination for each mature pollen accession of Brachiaria collected at the very beginning of anther dehiscence

\begin{tabular}{|c|c|c|c|c|c|c|c|c|c|c|}
\hline \multirow[t]{2}{*}{ Species accession } & \multirow[t]{2}{*}{ Ploidy } & \multirow[t]{2}{*}{$\begin{array}{l}\text { Total number } \\
\text { of pollen counted }\end{array}$} & \multicolumn{2}{|c|}{ Microspores n (\%) } & \multicolumn{2}{|c|}{$\begin{array}{l}\text { Vacuolated } \\
\text { pollen } 2 \mathrm{n}(\%)\end{array}$} & \multicolumn{2}{|c|}{$\begin{array}{l}\text { Mature pollen } \\
3 \mathrm{n}(\%)\end{array}$} & \multirow[t]{2}{*}{$\begin{array}{l}\text { Sucrose } \\
\text { range }(\%)\end{array}$} & \multirow[t]{2}{*}{$\begin{array}{l}\text { Average of pollen } \\
\text { germination }(\%)\end{array}$} \\
\hline & & & $\begin{array}{l}\text { Live } \\
\text { pollen }\end{array}$ & $\begin{array}{l}\text { Dead } \\
\text { pollen }\end{array}$ & $\begin{array}{l}\text { Live } \\
\text { pollen }\end{array}$ & $\begin{array}{l}\text { Dead } \\
\text { pollen }\end{array}$ & $\begin{array}{l}\text { Live } \\
\text { pollen }\end{array}$ & $\begin{array}{l}\text { Dead } \\
\text { pollen }\end{array}$ & & \\
\hline \multicolumn{11}{|l|}{ Sexual plants } \\
\hline B. ruziziensis $\mathrm{RS} 1$ & $(2 \mathrm{~N}=2 \mathrm{X})$ & 258 & 5 & 10 & 8 & & 76 & 1 & $20-10$ & 2 \\
\hline B. ruziziensis $\mathrm{RS} 3$ & $(4 N=4 X)$ & 388 & 22 & 39 & & & 39 & & $12-10$ & 1 \\
\hline B. decumbens DS1 & $(2 \mathrm{~N}=2 \mathrm{X})$ & 242 & 6 & 7 & & & 87 & & $35-25$ & 70 \\
\hline \multicolumn{11}{|l|}{ Apomictic plants } \\
\hline B. decumbens DA1 & $(2 \mathrm{~N}=4 \mathrm{X})$ & 259 & 41 & 20 & 5 & & 33 & 1 & $35-25$ & 10 \\
\hline B. decumbens DA2 & $(2 \mathrm{~N}=4 \mathrm{X})$ & 386 & 34 & 24 & 21 & 1 & 18 & 2 & $10-18$ & 70 \\
\hline B. humidicola $\mathrm{HA} 1$ & $(2 \mathrm{~N}=6 \mathrm{X})$ & 262 & 37 & 20 & 4 & & 39 & & $35-28$ & 28 \\
\hline
\end{tabular}


Fig. 1 Germination and elongation of pollen tubes of sexual Brachiaria decumbens DS1: a Many pollen tubes growing on the stigma, 7 HAP. Arrow tip of pollen tube entering the style, bar $30 \mu \mathrm{m}$; b Ovary with two styles and with a pollen tube reaching the micropyle (M), 24 HAP. Note autofluorescence of callose is probably in the cell walls of the phloem-like transport cell in the ovary wall, bar $30 \mu \mathrm{m}$; c Pollen collected from open anthers of DS1, $4 \mathrm{~h}$ after germination in culture medium, bar $30 \mu \mathrm{m}$; d Pollen collected from DS1 anthers opened under incandescent light, $4 \mathrm{~h}$ after germination in $33 \%$ sucrose culture medium, bar $30 \mu \mathrm{m}$
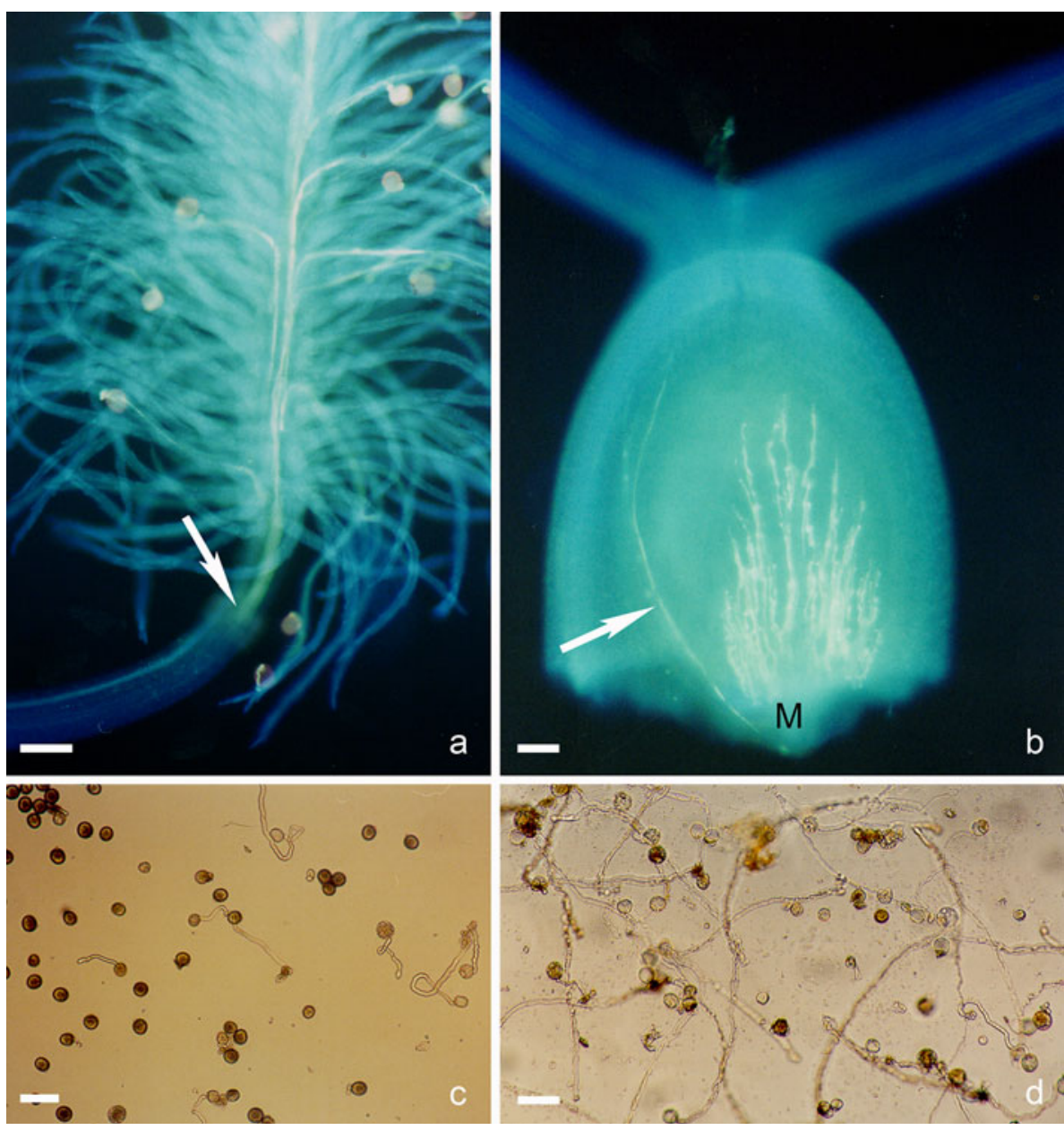

incandescent light. The high germination percentage was accompanied by more vigorous pollen tube growth, and tubes readily reached a length 10 times the pollen diameter (Fig. 1d). DAPI labeling confirmed that the sperm nuclei were present in the pollen tubes in vitro.

In vitro pollination

In vitro pollination success differed among the accessions used. Two hours after spreading the pollen grains near the bases of the ovaries of $B$. decumbens, sexual DS1, apomictic DA1 and apomictic B. humidicola HA1 plants, pollen tubes were observed. After $4 \mathrm{~h}$, pollen tubes were already located near the sectioned bases of the ovaries. Many pollen tubes adhered to the bases (Fig. 2a, b) prior to entering the ovule. Only one tube was observed to penetrate the ovule through the micropyle that is formed by the embellum cells (Fig. 2c, d). While some pollen tubes were directed toward the micropyle, others were found entering the ovule in the nucellar cells (Fig. 2e) and at the region between the ovary wall and outer integument of the ovule (Fig. 2f).
The percentage of ovaries with one or more pollen tube adhered onto the bases after $24 \mathrm{~h}$ in culture medium with $33 \%$ sucrose, ranged from $60 \%$ in HA1, $70 \%$ in DS1 up to $80 \%$ in DA1.

By clearing and staining with aniline blue $24 \mathrm{HAP}$, nine out of 41 ovaries (22\%) with pollen tube adhered to the bases had pollen tubes entering the nucellus toward the embryo sac. However, three out of four sectioned ovaries of the diploid sexual DS1 analyzed had collapsed embryo sacs 48 HAP. Only some remnants in the collapsed embryo sac were visible (Fig. 3a). An endosperm nucleus was observed inside the embryo sac of one of the ovaries, pointing to fertilization (Fig. 3b). In this embryo sac, the antipodals were degenerating. In other sections, it was evident that the egg apparatus was also degenerating. In sectioned ovaries at $48 \mathrm{HAP}$, it was difficult to trace a pollen tube penetrating the micropyle. Moreover, a clear penetration and good positioning of the sperm cells was not observed.

Within the apomictic accessions investigated, an ovule of the apomictic $B$. humidicola HA1 with one embryo sac had an aberrant feature in the presence of a chalazal 
Fig. 2 Pollen tube growth and entrance in the base of the ovary after in vitro pollination of sexual Brachiaria decumbens, DS1 24 HAP (a-d) and B. humidicola HA1 48 HAP (e-f) at the base of the ovaries: a-d Ovaries were stained with aniline blue and visualized using a fluorescence microscopy (a and d) or visualized with a differential interference contrast, DIC (b and c); a-b Pollen tubes adhered to a sectioned bases of the ovary, bars $30 \mu \mathrm{m}$, in $\mathbf{b}$ it is possible to observe part of the egg apparatus (arrow) inside the embryo sac; c One pollen tube (arrow) penetrating the ovule through the micropylar channel formed by the embellum cells (*), bar $3 \mu \mathrm{m}$; d Pollen tube penetrating between the embellum cells $(*)$, it is possible to visualize the edge of the pollen tube inside the embryo sac (arrowhead), note that the embellum cells have callose as shown by the fluorescence, bar $3 \mu \mathrm{m}$; e Semi-thin section of pollen tube (arrow) penetrating the ovary wall and entering the nucellar tissue, $\operatorname{bar} 8 \mu \mathrm{m}$; $\mathbf{f}$ Two sperm nuclei between the anther wall and outer integument, bar $7 \mu \mathrm{m}$
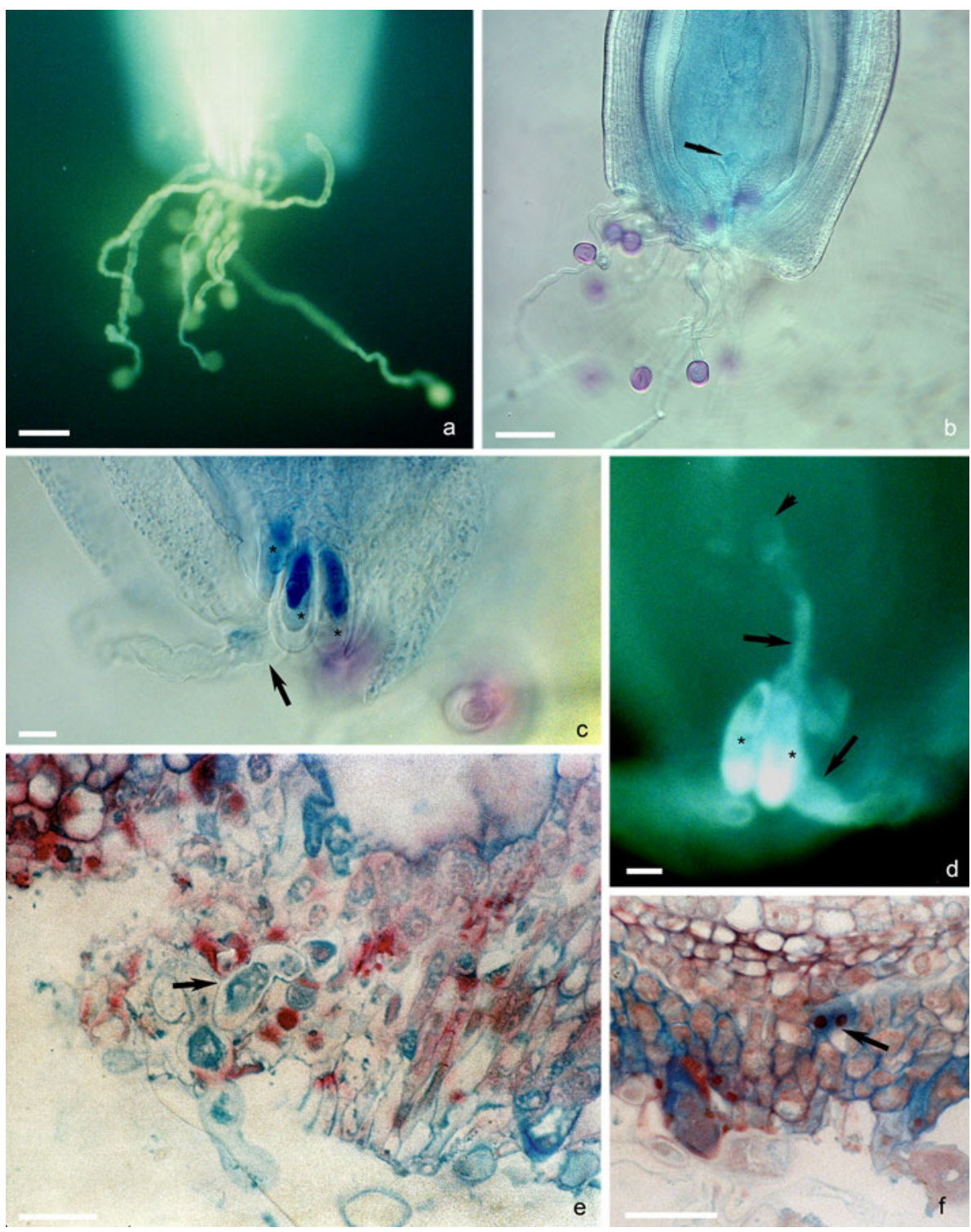

hypostase (Fig. 3c). In the ovaries of apomictic B. humidicola HA1 at 48 HAP, many embryo sacs were present, as in the other apomicts, and a few egg cells were positioned near the micropyle (Fig. 3d, e). A pollen tube was located near the egg apparatus (Fig. 3f).

In vitro pollination of $B$. decumbens apomictic DA1 led to the penetration of pollen tubes within the egg apparatus. All the cells of the egg apparatus were observed in one of the embryo sacs near the micropylar pole. In the observed egg apparatus $48 \mathrm{HAP}$, the egg cell had no signs of autonomous development (Fig. 4a). One synergid had degenerated and had a penetrated pollen tube and the nucleus of the vegetative cell was in the cell (Fig. 4b). In another plane of the same embryo sac, one sperm nucleus was already localized in the central cell, near the basal part, against the intact synergid, whereas the other sperm nucleus had entered the egg cell and was positioned near the nucleus of the egg cell (Fig. 4c).

\section{Discussion and conclusion}

Reproduction in seed plants is a process requiring precise interactions between the sporophyte and gametophyte that require synchrony and communication (Weterings and Russell 2004). Between these organisms, barriers can be present to prevent self-fertilization. One of the advantages of in vitro pollination can be to avoid such pollination barriers and to accomplish interspecific crossings. In vitro pollination enhances the possibility of pollen tube penetration into the egg apparatus and central cell. On the other hand, in vitro pollination indicates some additional conditions required to achieve fertilization. 
Fig. 3 In-vitro pollination with isolated ovaries. Semi-thin section of ovaries of sexual B. decumbens DS1 $(\mathbf{a}, \mathbf{b})$ and apomictic B. humidicola HA1 (c-f) 48 HAP, stained with astral blue and safranin: a Remnants of the collapsed embryo sac (arrow); bar $10 \mu \mathrm{m}$; b Embryo sac showing degenerating antipodal cells (AN) and endosperm nucleus (arrow), bar $5 \mu \mathrm{m}$; c Ovule with a structure resembling a hypostasis (arrow) bar $30 \mu \mathrm{m}$; d Three embryo sacs, the egg cell is not near the micropyle, bar $13 \mu \mathrm{m}$; e Closer view of another section of the egg cell showed in d, bar $2 \mu \mathrm{m}$; f Pollen tube near the embryo sac (arrow), bar $8 \mu \mathrm{m}$
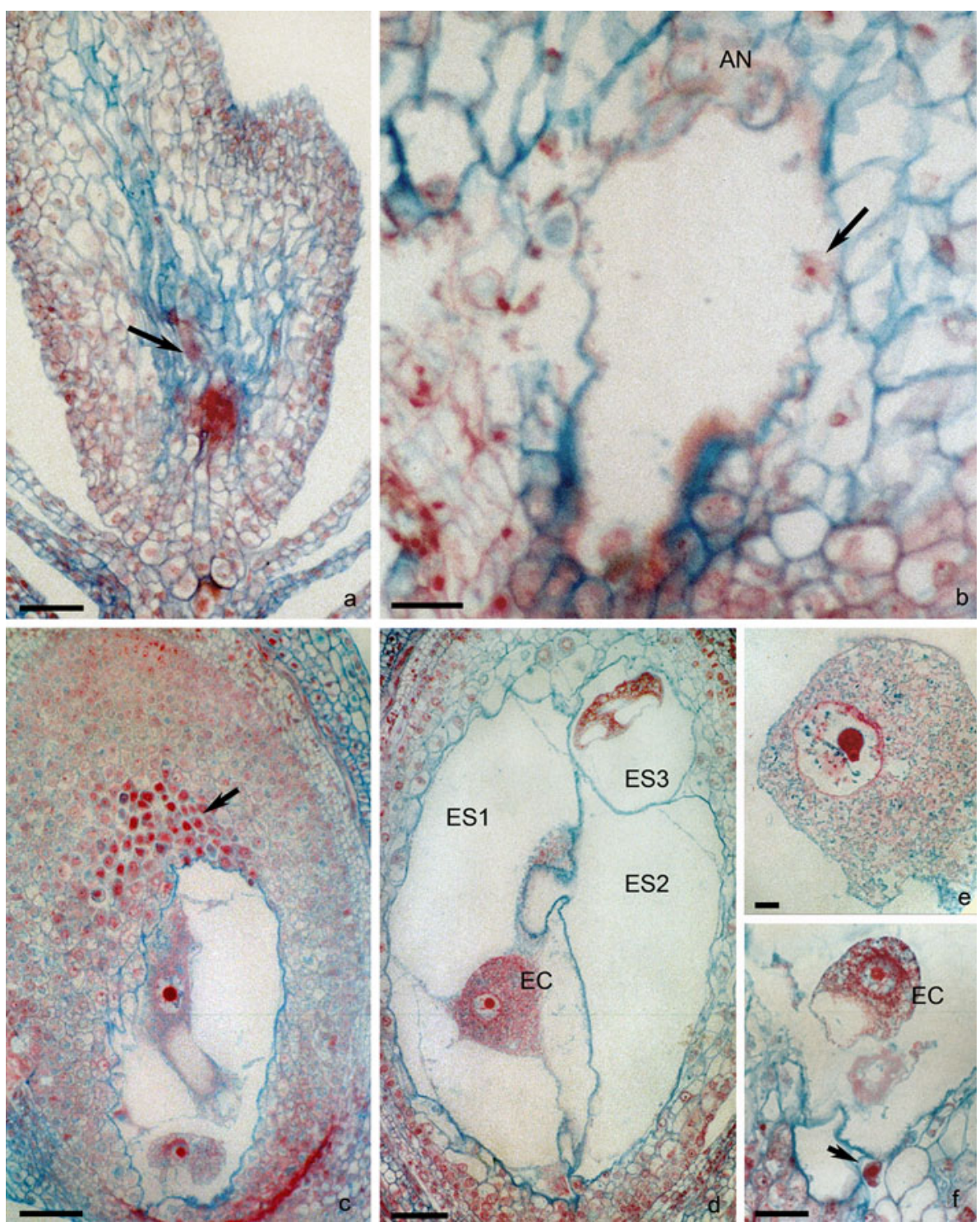

Pollen viability depends on the accession used and is more stable in the sexual accessions. In some accessions of Brachiaria used, pollen development was normal but in most of accessions development was hampered by lethality in the microspore stage, especially in apomicts. It is known that Brachiaria apomictic pollen has a higher level of abortion compared with the sexual pollen (Ngendahayo 1988; Dusi and Willemse 1999b; Alves 2000). In an earlier study during the period from February to June in Brazil, B. brizantha sexual BS1 viability was higher (87-90\%) and more consistent than in apomictic $B$. brizantha $\mathrm{cv}$. Marandu accession BRA000591 (35-72.5\%); the latter displayed a maximum value in April, which is the peak of the flowering season (Alves 2000). The high level of degeneration observed in early microspores may point to a lethal effect from the preceding male meiosis. The percentage of viability given in Table 1 had no direct relationship with sucrose percentages used in the medium, as well as the germination percentage, suggesting that viability, as tested, is no guarantee for in vitro germination success. The most viable pollen do not always display optimal germination, as is shown in B. ruziziensis RS1 with a $76 \%$ viability, but only $2 \%$ germination, or $B$. decumbens DA2 with a $18 \%$ viability level but $70 \%$ germination.

Anther condition is critical to obtain sufficient pollen germination. Anthers should remain in a humid chamber to improve pollen germination. In some Brachiaria accessions, in vitro pollen germination needs a relatively high concentration of sugar for suitable germination, which points to special water conditions in the cytoplasm and membranes.

Pollen collected from mature anthers either immediately before anthesis or at anthesis and opened under incandescent light gave the best percentage of pollen tube growth 


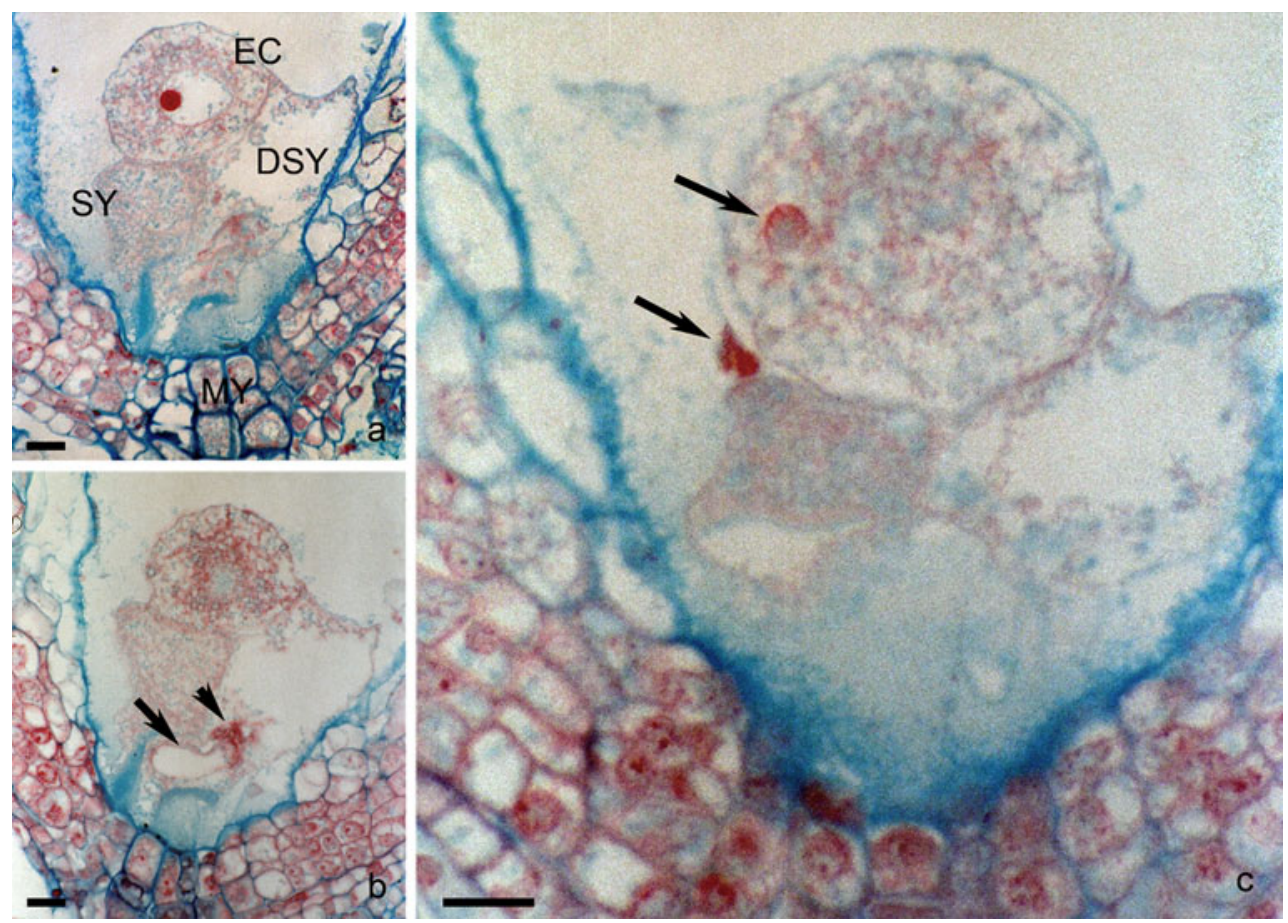

Fig. 4 Semi-thin sections of micropylar side of an ovary of apomictic B. decumbens DA1 48 HAP, stained with astral blue and safranin: a Egg apparatus with egg cell (EC) containing nucleus and nucleolus, synergid (SY) and degenerating synergid (DSY); bar $4 \mu \mathrm{m}$. b pollen tube (arrow) entering the degenerating synergid and the putative

and more vigorous growth. At this stage of development, the pollen grains are in a condition that triggers and maintain a good pollen tube growth. Analysis of the results leads to the conclusion that gradual drying of anthers is a crucial to obtain germinable pollen. In normal conditions, pollen is shed in the morning. Thereafter, pollen will contact nearby stigmatic hairs, or fly in the open air, moved by airflow or insects. After shedding in open air, the ability to germinate diminishes rapidly.

External circumstances also influence pollen condition. In fact, we observed that during rainy days or on the next day following a rain, pollen grains are not able to germinate. Consequently, in vitro pollination requires selecting the optimal accession and timing in culture; attention to culture conditions improve overall success and therefore reduce the effects of differences in the rate of pollen tube growth.

In the pistil, the small column of transmitting tissue in the style represents a mechanical barrier limiting the number of pollen tubes able to penetrate an ovary. Additionally, self-incompatibility has been described in sexual plants of the genus Brachiaria (Ngendahayo 1988). In the case where gametophytic self-incompatibility is present, the rejection can take place in the pistil, normally in the style by the arrest of pollen tube growth. Thus, both the mechanical barrier and self-incompatibility can be vegetative nucleus (arrow head); bar $4 \mu \mathrm{m}$. c Same embryo sac as in Fig. 4a and $\mathrm{b}$ with two sperm nucleus (arrows): one in the central cell near the synergid and the other inside the egg cell; bar $3 \mu \mathrm{m} . M Y$ micropyle

overcome by in vitro pollination. Inbreeding depression (Araujo et al. 2007) is also present in Brachiaria. Although some seed set was observed in sexual plants, apomictic plants have no self-incompatibility and good seed set, which could be reasons for more successful in vitro pollination in the apomicts than the sexual plants.

The use of a style for pollen germination in Torenia is required to activate targeting of pollen tubes (Higashiyama et al. 1998), but in Brachiaria this is not possible because of a barrier mechanism in the style. Potentially, this step may not be required, as in Gasteria (Willemse et al. 1995), where free pollen is easy to handle, efficient and fully functional.

In addition to pollen and ovule vigor, success of in vitro pollination requires pollen and ovary to be placed in a horizontal and steady bottom layer with good hydration and a medium optimized for pollen tube germination. Pollen grains placed near the ovaries should produce sufficient number and vigor of growing tubes to penetrate the base of the ovary.

In the present paper, we showed that in vitro Brachiaria spp. pollen tube growth is highly dependent on the species and on sucrose concentration in the culture medium. A 33\% sucrose concentration was chosen because it yielded the best germination rate and pollen tube growth. $B$. decumbens sexual diploid (DS1) and apomictic tetraploid (DA1, DA2) 
pollen were the best candidates for the in vitro fertilization experiments.

Many pollen tubes penetrated the ovary wall and integuments, but just one pollen tube was seen penetrating the micropylar channel, suggesting that selection of tubes in the micropyle occurs in both sexual and apomictic plants. This suggests a tendency to accept only one pollen tube to penetrate the ovule through the micropyle in vitro. Such selection is not a characteristic particular to Brachiaria but is considered as an important mechanism for preventing polyspermy and heterofertilization, the fertilization of the egg and central cells by sperm cells of different pollen tubes (Weterings and Russell 2004). However, in Gasteria the opening of the micropyle enlarges before fertilization and permits multiple penetrations (Willemse 1999). The embellum cells can be related to the pollen tube guidance. The sexual Brachiaria displayed callose deposition in the embellum cells during fertilization. In prior studies, this characteristic was also observed in the sexual plant during and after meiosis (Dusi and Willemse 1999b). Such a feature may explain differences found between in vitro pollination in sexual versus apomict accessions. The micropyle also seems to function in the selection of one pollen tube, as in rice (Chen et al. 2008). Such selection in the micropyle could be the result of products present and related to gametophyte-gametophyte incompatibility.

In the sexual Brachiaria, the arrest of pollen tube growth could be an action from the female gametophyte. Within the female gametophyte, the synergids are important in pollen tube attraction and pollen tube guidance and opening before fertilization (Jensen and Fisher 1968; Kapil and Bhatnagar 1975; Mogensen 1978, Van Went and Willemse 1984; Russell 1992; Weterings and Russell 2004; Dresselhaus 2006; Dresselhaus and Márton 2009). In maize, it was suggested that not only the synergids but also the egg cell could be involved in micropylar pollen tube guidance (Márton et al. 2005). A post-penetration repulsion, as reported for Arabidopsis (Palanivelu and Preuss 2006), cannot be excluded although polyspermy was never observed or reported in Brachiaria.

In the apomictic $B$. brizantha cv. Marandu, the degeneration of one of the synergids was associated with pollen tube discharge inside the embryo sac (Alves 2000; Alves et al. 2001). It is hypothesized that the synergids could also be cells involved in the expression of gametophyticgametophytic incompatibility (Ngendahayo 1988).

Barriers in the micropyle and the gametophytic-gametophytic incompatibility cannot be overcome by in vitro pollination. Observations of ovaries of sexual B. decumbens with remnants of endosperm nuclei and degeneration of other embryo sac cells, point to the likely occurrence of fertilization. Araujo et al. (2007) showed that in vivo pollination of the sexual $B$. brizantha can produce fertilized products, and that embryo and endosperm developed; however, the abortion of the caryopsis starting near anthesis suggested the occurrence of inbreeding depression. In sexual Brachiaria 48 HAP, most of the embryo sacs collapsed. Although it is possible that abortion occurred as a result of absence of fertilization, but this may also happen in the context of gametophytic-gametophytic incompatibility or early ovule abortion due to inbreeding depression. All the ovaries of open flowers studied had one or more well-developed embryo sacs. Collapse of the ovule or other parts of the ovary due to excision of the ovary was not observed. Ovaries on the medium showed no shrinkage and sections showed intact ovaries. Likewise, abortion during microspore development and collapse of the embryo sac during maturation can happen. In DS1, it is about $10 \%$.

After in vitro pollination of apomictic Brachiaria, penetration and discharge of vegetative and sperm nuclei were observed in the aposporic embryo sacs. The presence of nuclei inside the degenerated synergid observed in B. decumbens was also reported in vivo for B. brizantha $\mathrm{cv}$. Marandu (Alves 2000; Alves et al. 2001). Observation of this particular event demonstrates the normal method of transport in an in vitro pollination system. In vivo, the egg cell of the apomict, in contrast with the sexual plants, might already divide before the arrival of the sperm nucleus. This division was not observed in vitro, and a sperm nucleus was present in the cytoplasm of the egg cell. In Brachiaria, fertilization of the central cell is needed for endosperm development, which is characteristic of pseudogamy. Therefore, a mechanism must prevent the fertilization of the egg cell. Savidan (1989) suggests a physical barrier around the egg cell such as the cell wall present in Pennisetum ciliare (Vielle-Calzada et al. 1995). Another hypothesis is the early activation of the egg cell, which leads to embryo development in species with autonomous development (Nogler 1984; Dusi and Willemse 1999a; Araujo et al. 2000; Dusi 2001).

The system of in vitro pollination used in this study resulted in the transfer of sperm cells in apomicts and possibly in sexual plants as well, allowing control of pollen tube growth, attraction and penetration in the ovule. This method will permit testing of intra-specific and inter-specific crosses in Brachiaria. It will also open the possibility of exploring the residual sexual capacity of facultative apomicts. In vitro pollination will also permit introduction of new traits, which could have a significant impact in the breeding of this culture. Furthermore, this method provides an experimental system that facilitates detailed study of timing in fertilization processes, and particularly for analysis of gene expression in apomictic plants.

Acknowledgments This work was partially financed by grants from Brazilian Education Ministry (CAPES), National Council for 
Scientific and Technological Development, Brazil (CNPq) and InterAmerican Institute for Cooperation on Agriculture (IICA).

\section{References}

Alves ER (2000) Aspectos da reprodução em Brachiaria brizantha cv. Marandu. Dissertation. Universidade de Brasilia, BrasíliaDF, Brazil

Alves ER, Carneiro VTC, Araujo ACG (2001) Direct evidence of pseudogamy in an apomictic Brachiaria brizantha (Poaceae). Sex Plant Reprod 14:207-212

Araujo ACG, Mukhambetzhanov S, Pozzobon MT, Santana EF, Carneiro VTC (2000) Female gametophyte development in apomictic and sexual Brachiaria brizantha (Poaceae). Rev Cytol Biol Veg Le Botaniste 23:13-28

Araujo ACG, Nóbrega JM, Pozzobon MT, Carneiro VTC (2005) Evidence of sexuality in induced tetraploids of Brachiaria brizantha (Poaceae). Euphytica 144:39-50

Araujo ACG, Falcão R, Carneiro VTC (2007) Seed abortion in the sexual counterpart of Brachiaria brizantha apomicts (Poaceae). Sex Plant Reprod 20:109-121

Chen S-Q, Wang Z, Liu M-X, Xie Z-W, Wang H-H (2008) Pollen grain germination and pollen tube growth in pistil of rice. Science 15:125-130

de Andrade RP (2001) Pasture seed production technology in Brazil. In: SBZ ed, International Grassland Congress, vol 19. São Pedro, pp 129-132

do Valle CB (1986) Cytology, mode of reproduction and forage quality of selected species of Brachiaria Griseb. PhD Thesis, University of Wisconsin, Madison, USA

do Valle CB (1990) Coleção de germoplasma de espécies de Brachiaria no CIAT: estudos básicos visando ao melhoramento genético. Documentos 46:33

do Valle CB (1991) Avaliação de germoplasma e melhoramento genético de braquiarias. In VTea Paulino, ed, Encontro para discussão sobre espécies do gênero Brachiaria, vol 2. Nova Odessa, pp 301-342

do Valle CB, Savidan Y (1996) Genetics, cytogenetics and reproductive biology of Brachiaria. In: Miles JW, Maass BL, do Valle CB (eds) Brachiaria: biology, agronomy and improvement. CIAT-EMBRAPA, Cali, p 288

do Valle CB, Bitencourt GA, Chiari L, Resende RMS, Jank L, Arce AQ (2008a) Identification of the mode of reproduction in Brachiaria humidicola hybrids. In International Congress on Sexual Plant Reproduction, 20, 2008, Brasília. Documentos, 259. Brasília: Embrapa Recursos Genéticos e Biotecnologia p. 197

do Valle CB, Bitencourt GA, Arce AQ, Chiari L, Jank L, Resende RMS, Calixto S (2008b) Preliminary evaluation of Brachiaria humidicola hybrids. In: International Grassland Congress, 20, 2008, Hohhot. Multifunctional Grasslands in a Changing World, vol. 2. Guangdong People's Publishing House, Beijing. p 418

Dresselhaus T (2006) Cell-cell communication during double fertilization. Curr Opin Plant Biol 9:41-47

Dresselhaus T, Márton ML (2009) Micropylar pollen tube guidance and burst: adapted from defense mechanisms? Curr Opin Plant Biol 12:773-780

Dusi DMA (2001) Apomixis in Brachiaria decumbens Stapf. PhD thesis. University of Wageningen, The Netherlands

Dusi DMA, Willemse MTM (1999a) Activity and localisation of sucrose synthase and invertase in ovules of sexual and apomictic Brachiaria decumbens. Protoplasma 208:173-185

Dusi DMA, Willemse MTM (1999b) Apomixis in Brachiaria decumbens Stapf.: gametophytic development and reproductive calendar. Acta Biol Cracov Soc Bot 41:151-162
Gobbe J, Swenne A, Louant B-P (1981) Diploïdes naturels et autotetraploïdes induits chez Brachiaria ruziziensis Germain et Evrard: critères d'identification. Agro Tropic 36:339-346

Higashiyama T, Kuroiwa H, Kawano S, Kuroiwa T (1998) Guidance in vitro of the pollen tube to the naked embryo sac of Torenia fournieri. Plant Cell 10:2019-2031

Holmberg B (1961) On the permeability to lissamine green and other dyes in the course of cell injury and cell death. Exp Cell Res 22:406-414

IBGE Instituto Brasileiro de Geografia e Estatística (2006) Censo Agropecuário 2006-Resultados preliminares http://www.ibge.gov. br/home/presidencia/noticias/noticia_visualiza.php?id_noticia= 1064\&id pagina=1. Accessed 18 Jun 2009

Jensen WA, Fisher DB (1968) Cotton embryogenesis: entrance and discharge of the pollen tube in the embryo sac. Planta 78:158183

Kapil RN, Bhatnagar AK (1975) A fresh look at the process of double fertilization in angiosperms. Phytomorphology 50:334-368

Karia CT, Duarte JB, Araujo ACG (2006) Desenvolvimento de cultivares do gênero Brachiaria (trin.) Griseb. no Brasil. Documentos 163:1-57

Kaushal P, Sidhu JS (2000) Pre-fertilization incompatibility barriers to interspecific hybridizations in Pennisetum species. J Agric Sci 134:199-206

Lapointe SL, Miles JW (1992) Germplasm case study: brachiaria species. In: CIAT (ed) Pastures for the tropical lowlands. CIAT's contribution, CIAT, CALI, Colombia, pp 43-55

Márton ML, Cordts S, Broadhvest J, Dresselhaus T (2005) Pollen tube guidance precedes the double fertilization of flowering plants. Science 307:573-576

Miles JW, do Valle CB (1991) Assessment of reproductive behavior of interespecific Brachiaria hybrids. Apomixis Newsl 3:9-10

Miles JW, Maass BL, do Valle CB (1996) Brachiaria: biology, agronomy and improvement, vol 1, 1st edn. CIAT, Cali

Mogensen HL (1978) Pollen tube-synergid interactions in Proboscidea louisianica (Martineaceae). Am J Bot 65:953-964

Ngendahayo M (1988) Méchanismes de la reproduction dans le genre Brachiaria. Doctor thesis. Université Catholique de Louvain, Louvain-Belgium

Nogler GA (1984) Gametophytic apomixis. In: Johri BM (ed) Embryology of Angiosperms. Springer, Berlin, pp 475-518

Palanivelu R, Preuss D (2006) Distinct short-range ovule signals attract or repel Arabidopsis thaliana pollen tubes in vitro. BMC Plant Biol 6:7

Pinheiro AA, Pozzobon MT, do Valle CB, Penteado MIO, Carneiro VTC (2000) Duplication of the chromosome number of diploid Brachiaria brizantha plants, using colchicine. Plant Cell Rep 19:274-278

Risso-Pascotto C, Pagliarini MS, do Valle CB (2006) A new basic chromosome number for the genus Brachiaria (Trin) Griseb (Poaceae: Panicoideae: Paniceae). Genet Resour Crop Evol 53:7-10

Russell SD (1992) Double fertilization. Intl Rev Cytol 140:357-388

Savidan Y (1989) Another "working hypothesis" for the control of parthenogenesis in Panicum. Apomixis Newsl 1:47-51

Sladký Z, Havel L (1976) The study of the conditions for the fertilization in vitro in maize. Biol Plant 18:469-472

Swenne A, Louant BP, Dujardin M (1981) Induction par la colchicines de formes autotetraplo1des chez Brachiaria ruziziensis Germain et Evrard (Graminée). Agron Trop 36:134-141

Valério JR, Lapointe SL, Kelemu S, Fernandes CD, Morales FJ (1996) Pests and diseases of Brachiaria species. In: Miles JW, Maass BL, Valle CBdo (eds) Brachiaria: biology, agronomy and improvement. CIAT, Cali, pp 87-105

Van Went JL, Willemse MTM (1984) Fertilization. In: Johri BM (ed) Embryology of angiosperms. Springer, Berlin, pp 274-317 
Vielle-Calzada J-P, Burson BL, Bashaw EC, Hussey MA (1995) Early fertilisation events in the sexual and aposporous egg apparatus of Pennisetum ciliare (L.) Link. Plant J 8:309-316

Weterings K, Russell SD (2004) Experimental analysis of the fertilization process. Plant Cell 16:S107-S118

Willemse MTM (1999) Pollen coat signals with respect to pistil activation and ovule penetration in Gasteria verrucosa (Mill.)
H. Duval. In: Cresti M, Cai G, Moscatelli A (eds) Fertilization in higher plants. Springer, Berlin, pp 145-156

Willemse MTM, Plyush TA, Reinders MC (1995) In vitro micropylar penetration of the pollen tube in the ovule of Gasteria verrucosa (Mill.) H. Duval and Lilium longiflorum Thumb.: conditions, attraction and applications. Plant Sci 108:201-208 